"Good management or good finances? An agent-based study on the causes of bank failure"

\begin{tabular}{|c|c|}
\hline & Stathis Polyzos (D) https://orcid.org/0000-0002-4317-1809 \\
\hline AUTHORS & $\begin{array}{l}\text { Khadija Abdulrahman } \\
\text { Apostolos Christopoulos }\end{array}$ \\
\hline ARTICLE INFO & $\begin{array}{l}\text { Stathis Polyzos, Khadija Abdulrahman and Apostolos Christopoulos (2018). } \\
\text { Good management or good finances? An agent-based study on the causes of } \\
\text { bank failure. Banks and Bank Systems, 13(3), 95-105. } \\
\text { doi:10.21511/bbs.13(3).2018.09 }\end{array}$ \\
\hline DOI & http://dx.doi.org/10.21511/bbs.13(3).2018.09 \\
\hline RELEASED ON & Tuesday, 11 September 2018 \\
\hline RECEIVED ON & Friday, 25 May 2018 \\
\hline \multirow[t]{2}{*}{ ACCEPTED ON } & Wednesday, 15 August 2018 \\
\hline & $($ (c) $)$ EY-NC \\
\hline LICENSE & $\begin{array}{l}\text { This work is licensed under a Creative Commons Attribution-NonCommercial } 4.0 \\
\text { International License }\end{array}$ \\
\hline JOURNAL & "Banks and Bank Systems" \\
\hline ISSN PRINT & 1816-7403 \\
\hline ISSN ONLINE & $1991-7074$ \\
\hline PUBLISHER & LLC "Consulting Publishing Company "Business Perspectives" \\
\hline FOUNDER & LLC "Consulting Publishing Company "Business Perspectives" \\
\hline
\end{tabular}

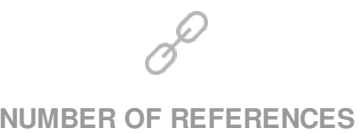

44

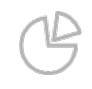

NUMBER OF FIGURES

4

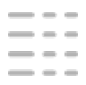

NUMBER OF TABLES

3

(C) The author(s) 2021. This publication is an open access article. 


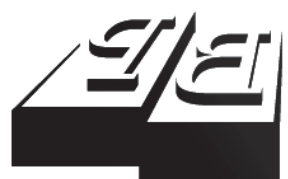

BUSINESS PERSPECTIVES

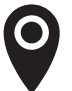

LLC "CPC "Business Perspectives" Hryhorii Skovoroda lane, 10, Sumy, 40022, Ukraine

www.businessperspectives.org

Received on: $25^{\text {th }}$ of May, 2018 Accepted on: $15^{\text {th }}$ of August, 2018

(c) Stathis Polyzos, Khadija Abdulrahman, Apostolos Christopoulos, 2018

Stathis Polyzos, Ph.D., Department of Business Administration, Business School, University of the Aegean, Greece.

Khadija Abdulrahman, Assistant Professor, College of Business, Zayed University, United Arab Emirates.

Apostolos Christopoulos, Lecturer of Banking and Finance, Faculty of Economics, University of Athens, Greece.
Stathis Polyzos (Greece), Khadija Abdulrahman (United Arab Emirates),

Apostolos Christopoulos (Greece)

\section{GOOD MANAGEMENT OR GOOD FINANCES? AN AGENT-BASED STUDY ON THE CAUSES OF BANK FAILURE}

\begin{abstract}
The recent series of banking crises in the United States and in the Eurozone has resulted in numerous bank failures. In this paper, an agent-based model is employed to test for factors that determine bank viability in times of distress, focusing mainly on the endogenous risk of financial institutions. The authors test for the effects of both management and financial factors on the institutions' ability to weather the storm during times when the banking system experiences distress. The agent-based simulation process is split into a setup period, when the simulation builds the structural characteristics of each bank, and a testing period, where these characteristics are tested against the final result, which is the bank's viability. A risk estimation model is built and it is found that the proposed model is successful in predicting whether a particular bank can endure a stress testing situation. The empirical results confirm the relevant literature and put further emphasis on the policy implications regarding banking supervision and regulation, particularly in context of the Eurozone banking union.
\end{abstract}

Keywords

JEL Classification corporate governance, agent-based finance, endogenous risk, bank management

\section{INTRODUCTION}

The world banking system has vivid memories from the financial turmoil of 2008, where several financial institutions were faced with extremely strenuous conditions. The 2008 crisis extended beyond the financial sector, hurting total output and thus damaging societal prosperity. Researchers still attempt to locate the distinguishing characteristics of banks, which allowed some to recover from the crisis and drove others to default. Most argue that there must exist a set of traits, ranging from sound management to solid finances, that would permit a forecast of the ability of a bank to weather the storm during distress.

In this paper, an agent-based model is employed in order to examine the causes of bank distress. It is proposed that banks fail due to both financial and corporate governance factors and introduce these features in the authors modelling platform. The authors of the current article attempt a link between these characteristics of the financial institution and its final state at the end of the simulation and employ this link to develop a simple forecasting model, verifying its robustness.

The current paper contributes to three aspects of the existing literature. Firstly, to the best of the authors' knowledge, it is the first effort to utilize an agent-based modelling platform as the medium with which to carry out simulations in the fields of management and corporate governance. Secondly, the validity of the results of existing literature
This is an Open Access article, distributed under the terms of the Creative Commons Attribution-NonCommercial 4.0 International license, which permits re-use, distribution, and reproduction, provided the materials aren't used for commercial purposes and the original work is properly cited. 
on the causes of bank failure is tested. Thirdly, possible policy implications are examined with respect to banking supervision, especially in the context of protecting societal prosperity.

The paper is structured as follows: Section 1 presents the relevant literature. In Section 2, the agentbased model is discussed and its main points are briefly presented. Section 3 includes the methodologi$\mathrm{cal}$ issues of the research work and the variables used. In Section 4, the outcome of the simulations is presented and the last Section includes the concluding remarks.

\section{LITERATURE REVIEW}

There exists a new trend in academic research that has turned the focus on modelling bank survivability as opposed to profitability, which was the favored topic before the financial crisis of 2008. Existing studies mainly examine risk and risk management and have linked these to the financial characteristics of banks. Philippas et al. (2015) implement the $\operatorname{SIR}^{1}$ epidemiological model in an effort to predict the final state of a bank during a banking crisis. Haq and Heaney (2012) find a significant negative relationship between total banking risk and the dividend payout ratio, which they attribute to the effort of banking firms to increase income for their shareholders. Broll et al. (2015) also attempt to model the relationship between risk and return in banking institutions.

Note that some researchers make the case that greater risk-taking can be in the best interest of shareholders in the presence of deposit insurance (Beltratti \& Stulz, 2009). Caluzzo and Dong (2015) suggest that risk in the financial sector has shifted away from individual risk towards systemic risk, adding that banking systems are now more susceptible to systemic contagion (as opposed to contagion in the banking system). Simper et al. (2015) also show that risk management practices play an important part in bank performance.

Contrary to existing research on bank performance and viability, this paper expands to the field of management and additionally includes corporate governance features. Macey and O'Hara (2003) provide a thorough review of corporate governance in the banking sector and its implications on the financial institutions and on the economic system as a whole. O'Connor and Byrne (2015) show that "sound" corporate governance is linked with firm maturity. Barr et al. (1993) also demonstrate that management quality is closely linked with bank survivability. Sullivan and Spong (2007) show that insider wealth limits risk-taking behavior, whereas stock ownership by hired managers may increase risk. Additionally, wealth concentration, which is the proportion of one's wealth at risk in a given financial institution, was also showed to have a positive effect on risk management (lower total risk), provided that the individual is in a position to influence relevant managerial decisions (Iannotta et al., 2007). Konishi and Yasuda (2004) examine the Japanese banking sector and reach similar conclusions, establishing a nonlinear empirical relationship of stable ownership and banking risk. García-Marco and Robles-Fernández (2008) corroborate these findings for the Spanish market.

Kangis and Kareklis (2001) demonstrate that the mix between public and private ownership can have an effect on bank performance. Barry et al. (2011), and Haque and Shahid (2016) also confirm the results showing the important role of ownership structure, especially for privately owned banks, where institutional investors tend to implement riskier strategies when owning higher stakes in banks. $\mathrm{Wu}$ and $\mathrm{Li}$ (2015) examine Chinese firms and comment positively on the effects of board independence on firm performance, while Kaur Virk (2017) shows that board independence is linked with a smaller number of regulatory violations. Laeven and Levine (2009) and Mullineux (2006) also stress the importance of regulation.

Williams and Nguyen (2005) implement the technical inefficiency effects model of Battese and Coelli (1995) using bank governance variables, similar to ours. This methodology was employed in the current article in order to implement

1 The SIR Model is a compartmental model in Epidemiology which classifies the population into three health states: Susceptible, Infected, Recovered (thus SIR). In mathematical epidemiology, compartmental models help understand the dynamics of the spread of an epidemic. 
a risk-governance index in the authors model, which describes bank features that tend to show "sound" management strategies. Additionally, Gupta et al. (2013) employ an additive index to quantify forty two bank governance factors. They find that corporate governance "failed" during the financial crisis, since the factors that existing literature considered as positive did little to help large corporations. A similar index is constructed by Koerniadi et al. (2014), who find that good governance practices are associated with lower levels of risk. Agoraki et al. (2010) link board size and composition to bank efficiency, suggesting that a small board size may signify better risk management. Similar results are demonstrated in Conyon and Peck (1998), who find that a smaller board size results in better corporate performance.

ElKelish (2017) performs a multi-country analysis of corporate governance risks, linking them to agency costs. Similarly, Aebi et al. (2012) propose a series of measures of corporate governance that are better suited to the banking sector. They use empirical data from banks in Europe and in the US and find that independent risk management is crucial to the bank's performance during a financial crisis. On the other hand, standard governance indicators seem to contribute little, if at all, to the amelioration of these results. However, they note the negative effects of risk governance on performance during "normal" times, using common performance indicators for the banking sector. Reddy and Locke (2014) reach similar conclusions from data regarding firms in New Zealand.

\section{GENERAL MODEL DESCRIPTION}

The agent-based financial model employed was developed by Samitas and Polyzos (2015) and extended by Polyzos and Samitas (2015). The model was designed to simulate the behavior of economic agents and is loosely based on the work of Tsomocos (2003a, 2003b). However, the Tsomocos model was extended to include agent-based characteristics, which are a new trend often seen in simulation research (see for example Bookstaber et al., 2018, and Riccetti et al., 2015). The specific agent-based model has also been used to simulate the post-Brexit economic system (Samitas et al., 2018) and has also been applied to the Greek banking system (Samitas \& Polyzos, 2015).

The model incorporates three main types of economic agents, namely Banks, Households and Firms. These agents operate under a given supervisory framework, which is set forth by a market regulator. In this setup, there is a constant, but not unconditional, flow of funds between these agents, which can take place in various ways, ranging from the exchange of financial goods between banks and their customers to the payment of wages from firms to households. Firms operate and improve their productive capacity using financing from the banking system, which draws liquidity from the funds of depositors. The model also employs the idea that agents can go bankrupt. Bankruptcy occurs when agents are unable to meet their financial obligations. The insolvency conditions are stricter for banks than they are for other agents and, naturally, the consequences are different as well. The model supports various methods of handling banks in distress, including the bail-in solution, which was implemented to resolve the 2013 Cyprus financial crisis.

\section{METHODS}

A thorough description of the latest version of the model, including a formal model definition, can be found in Samitas et al. (2018). In the current paper, this work is extended, in order to model the risk of financial institutions according to both their financial and their corporate governance characteristics. Each of the governance features influences the bank's behaviour in a different manner; this is something that the agent-based nature of the authors model allows to implement. The financial features are calculated at a snapshot of the financial institution after some time periods have elapsed. It must be noted that the proposed methodology does not examine bank performance, efficiency or profitability. At the current stage, these are not handled by the extension of the model, since the goal was to examine the causes of failure, rather than the causes of success.

Extending the Samitas et al. (2018) model, specific characteristics have been introduced for each bank. These variables are monitored in order to 
link them with the end state of each financial institution and to try to deduce an underlying relationship. In terms of governance features, the first monitored variable in the simulation is the presence of a Credit Risk Officer (CRO) in the executive board. Aebi et al. (2012) suggest that when the $\mathrm{CRO}$ has an active say in the executive board, this generally results in better risk management. In the current implementation, the bank is more capable of discerning the probability of firms to default on their loans. Additionally, banks with a CRO in the board of directors have the capacity to offer financing at customized interest rates, according to the credit status of the borrower ${ }^{2}$.

Another variable implemented is the board size. Aebi et al. (2012) and Beltratti and Stulz (2009) show that a smaller board size can work in the benefit of flexibility allowing the bank to respond faster to changing market conditions. Both studies propose the use of further measures regarding the Board of Directors, such as the attendance of members to board meetings, but these were not included in the authors simulations. However, if the board size is too small, it is possible that the lack of polyphony will hinder effective risk management. In the proposed model, a large board size has a negative effect on the ability of the bank to offer the appropriate interest rate for each firm and to set its base deposit rate, which effects both its cost of capital and its earnings ${ }^{3}$.

The board independence, which is the percentage of board members without further relation to the bank, is also an implemented variable. Additionally, a variable measuring the director experience has been included, which is calculated as the number of directors in the board with financial background. Aebi et al. (2012) have implemented this variable as the percentage of directors with experience as an executive officer in a bank or insurance company. Both these variables tend to improve risk management as they increase.

In terms of ownership, three variables have been included, namely the percentage of total equity owned by the $\mathrm{CEO}^{4}$, the percentage owned by the public sector and the percentage owned by institutional investors. It has been shown (Barry et al., 2011) that institutional investors tend to enforce riskier strategies when their ownership percent permits them to exert managerial control. On the other hand, Barry et al. also show that public sector ownership is associated with lower risk, while other research (Iannotta et al., 2007) suggests lower loan quality and higher insolvency. Ownership concentration is associated with better risk management (Iannotta et al., 2007), while a high CEO ownership seems to reduce overall risk (Sullivan \& Spong, 2007).

The monitored financial variables include the bank's ratio of assets to liabilities ${ }^{5}$ and the ratio of loans to deposits as shown below:

Assets to Liabilities ${ }_{b}=\frac{\sum_{a \in A_{b, t=10}} A m t_{a, t=10}}{\sum_{l \in L_{b, t=10}} A m t_{l, t=10}}$,

Loans to Deposits $_{b}=$

$=\frac{\sum_{a_{b, t} \in A_{b, t=0}} A m t_{a, t=10}}{\sum_{l_{b, t} \in L_{b, t=10}} A t_{l, t=10} \text { where } 1 \text { is of type Deposit }}$.

In terms of the bank's position in the marketplace, the ratio of the average interest rate of deposits and the ratio of the average interest rate of loans over the market average were computed.

$$
\begin{aligned}
& \text { Average Interest Rate }(\text { Loans })_{b}= \\
& =\frac{\frac{\sum_{a \in A_{b, t=10}} i r_{a, t=10} \times A m t_{a, t=10}}{\sum_{a \in A_{b, t=10}} A m t_{a, t=10}}}{\text { Market Average }} .
\end{aligned}
$$

Average Interest Rate (Deposits) $)_{b}=$

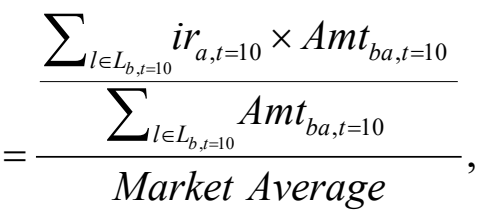

where $l$ is of type Deposit.

\footnotetext{
See step 1.12 of the basic model, where the active firms seek financing from banks from their proposed investment projects.

This is handled at step 1.11 of the basic model.

CEO: Chief Executive Officer.

Note that this ratio will differ greatly from the expected values of a real-world bank, since the authors are only simulating part of a financial institution's balance sheet.
} 
Also, the model uses the average spread (denoted by the average interest rate of loans minus that of deposits) and the profit margin, which is the average interest rate of loans less the $\mathrm{WACC}^{6}$. The latter is the weighted average of the interest rates of the bank's liabilities.

$$
\begin{aligned}
& \text { Average } \operatorname{Spread}_{b}=\frac{\sum_{a \in A_{b, t=10}} i r_{a, t=10} \times A m t_{a, t=10}}{\sum_{a \in A_{b}, t=10} A m t_{a, t=10}}- \\
& -\frac{\sum_{l \in L_{b, t=10}} i r_{a, t=10} \times A m t_{b a, t=10}}{\sum_{l \in L_{b, t=0}} A m t_{b a, t=10}}
\end{aligned}
$$

where $l$ is of type Deposit.

$$
\begin{aligned}
& \text { Profit Margin }_{b}=\frac{\sum_{a \in A_{b, t=10}} i r_{a, t=10} \times A m t_{a, t=10}}{\sum_{a \in A_{b, t=10}} A m t_{a, t=10}}- \\
& -\frac{\sum_{l \in L_{b, t=10}} i r_{a, t=10} \times A m t_{b a, t=10}}{\sum_{l \in L_{b, t=10}} A m t_{b a, t=10}} .
\end{aligned}
$$

Note that equations 5 and 6 differ in the fact the latter takes into account all liabilities of the bank (i.e. includes interbank loans), while the former only considers deposits.

With respect to the particulars of the banking sector, the authors monitor the amount of cash over the weighted assets ${ }^{7}$, the percentage of non-performing loans on total loans and the interbank exposure of the bank, which is the percentage of interbank loans over on loans. Increased interbank exposure has been shown to deteriorate a bank's expected viability due to increased contagion risks (Drehmann \& Tarashev, 2013).

$$
\text { CashtoWeighted Assets }{ }_{b}=\frac{C B_{b, t=10}}{w a_{b, t=10}},
$$

$$
N P L s_{b}=
$$$$
=\frac{\sum_{a^{\prime} \in A_{b, t=10}} A m t_{a^{\prime}, t=10} \text { where }^{\prime} \text { has missed payments }}{\sum_{a \in A_{b, t=10}} A m t_{a, t=10}},
$$

Interbank Exposure $_{b}=$

$$
=\frac{\sum_{a^{\prime} \in A_{b, t=10}} A_{m t^{\prime} t, t=10} \text { suchthat } a^{\prime} \in L_{b^{\prime}, t=10} b^{\prime} \in B}{\sum_{a \in A_{b, t=10}} A m t_{a, t=10}} \text {. }
$$

After the implementation of these variables in the proposed agent-based model, a virtual economy is designed, consisting of 1,000 households, 10 banks and 40 firms. Basel III was enforced as a regulatory framework for the banking system and a bail-in was the solution of choice for the Regulator to save a bank in distress. The time span for each simulation was 30 periods and 10,000 simulations were executed.

The governance features were assigned to each bank at the start of the simulation. Their values are random and the probability distribution has been manipulated to follow the findings of Aebi et al. (2012), who recorded these variables over a large sample of international banks. Each bank is logged in the system with these variables at the start of each simulation. The financial variables were recorded at period 10, when the banks had enough time to interact with firms and households, in order to build their asset and liability list. The final state of the bank was then recorded, given four alternatives, as follows:

- Bankrupt: In this state, the bank has gone bankrupt. Note that in this case, the Regulator was unable to rescue the bank, using the deposits the bank carries.

- Needs financing: In this state, the bank is still working but is unable to meet the requirements of the regulatory framework and will need a cash injection.

- Balanced: This is the initial state of the bank. This state will be assigned to banks in all cases where they cannot be included in any other state.

- Prosperous: This is the ideal state of the bank. In this case, the bank's total assets including its available cash exceed its liabilities. This state is an indication that the bank is well equipped to deal with financial distress.

The final state of the bank is the dependent variable on the regression analysis proposed by the authors. It was examined which of the above var-

$6 \quad$ Weighted Average Cost of Capital.

7 This could be considered an approximation to the Tier-1 capital. 
Table 1. Summaries of monitored variables for each final state

\begin{tabular}{|c|c|c|c|c|}
\hline & Bankrupt, \% & Needs financing, $\%$ & Balanced, $\%$ & Prosperous, $\%$ \\
\hline No CRO in board & 66.0 & 61.0 & 53.0 & 53.0 \\
\hline CRO in board & 34.0 & 39.0 & 47.0 & 47.0 \\
\hline Board size (independent/dependent members) & $12(8 / 4)$ & $13(8 / 5)$ & $13(9 / 4)$ & $13(9 / 4)$ \\
\hline CEO ownership & 20.5 & 23.7 & 25.2 & 25.2 \\
\hline Public ownership & 28.6 & 28.1 & 37.2 & 30.5 \\
\hline Institutional ownership & 20.9 & 23.2 & 22.6 & 24.3 \\
\hline Assets to liabilities & 1,221 & 1,098 & 73 & 691 \\
\hline Loans to deposits & 3,702 & 2,165 & 156 & 1,494 \\
\hline Deposit rate to market average & 101.8 & 97.4 & 93.7 & 93.9 \\
\hline Loan rate to market average & 102.3 & 97.2 & 94.2 & 95.3 \\
\hline Spread & 6.41 & 5.95 & 5.88 & 5.91 \\
\hline Profit margin & 5.28 & 5.42 & 5.58 & 5.42 \\
\hline Non-performing loans & 9.88 & 15.38 & 1.59 & 9.16 \\
\hline Interbank exposure & 28.7 & 54.4 & 1.4 & 39.3 \\
\hline Cash to weighted assets & 25.6 & 24.6 & 36.1 & 31.8 \\
\hline
\end{tabular}

Note: This table includes the summaries of monitored variable of the simulation set, for each of the final states of banks. The summary for the CRO variables is the percentage of the banks where the particular feature was true, except for the board size, which shows the average number of members. The summaries for the financial variables, as well as of ownership variables (CEO ownership, public ownership and institutional ownership) represent the average values recorded at the snapshot period (period 10), linked with the end state of the bank after the end of the simulation.

iables are significant in the prediction of the final state and a forecasting model was built to predict the outcome of the simulations. This methodology is similar to Aebi et al. (2012), the difference being that the data is generated from the simulations of the model. Following this process, the model was executed again to verify its predictive efficiency. The results are presented in the following section.

\section{EMPIRICAL RESULTS}

Table 1 shows a summary of the monitored variables for each of the four final states. The sample is 100,000 banks $(10,000$ simulations with 10 banks each) with random governance features, as described earlier. This table shows the distribution patterns for each of the variables over the entire sample of 100,000 observations, according to the final states. The table is indicative of the firm link between the bank's final state and both its governance and financial features.

Firstly, it is clear that CRO presence improves the bank's final state, since the worse-off states show lower average CRO presence in the board of directors (Figure 1). The board size does not seem important in determining the final state, but it seems that an increased number of independent members is beneficial (Figure 2).

In terms of the ownership structure, it is evident that a larger value in CEO ownership as well as in institutional ownership will tend to improve the

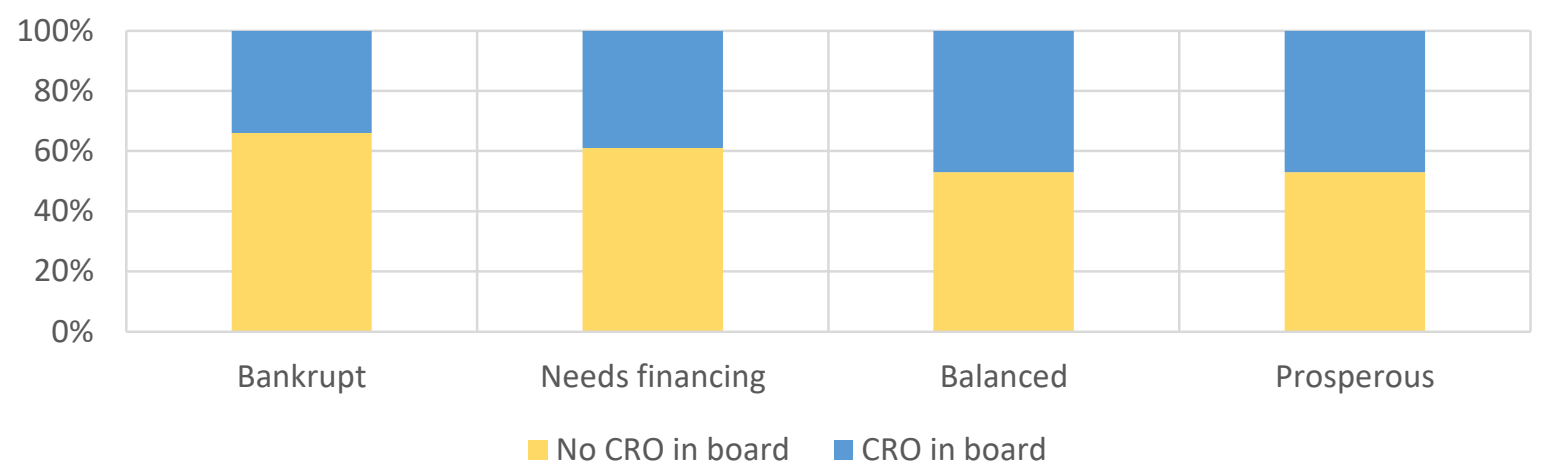

Figure 1. CRO presence for each of the four final states 


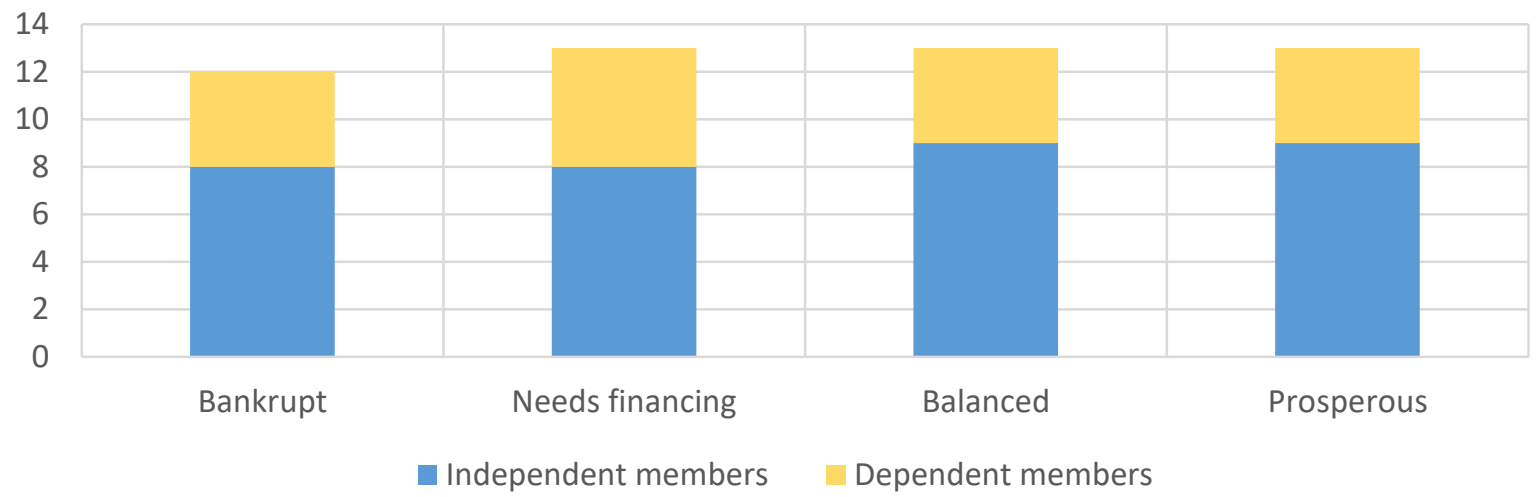

Figure 2. Dependent and independent board members for each of the four states

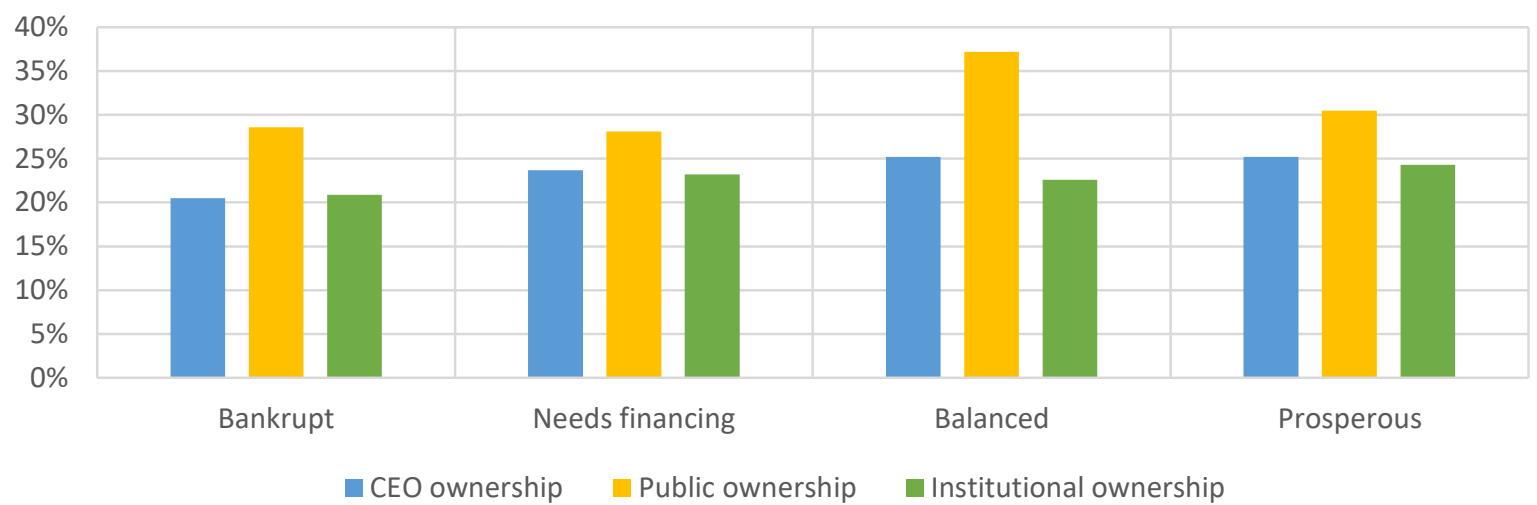

Figure 3. Average ownership percentages for each of the final states

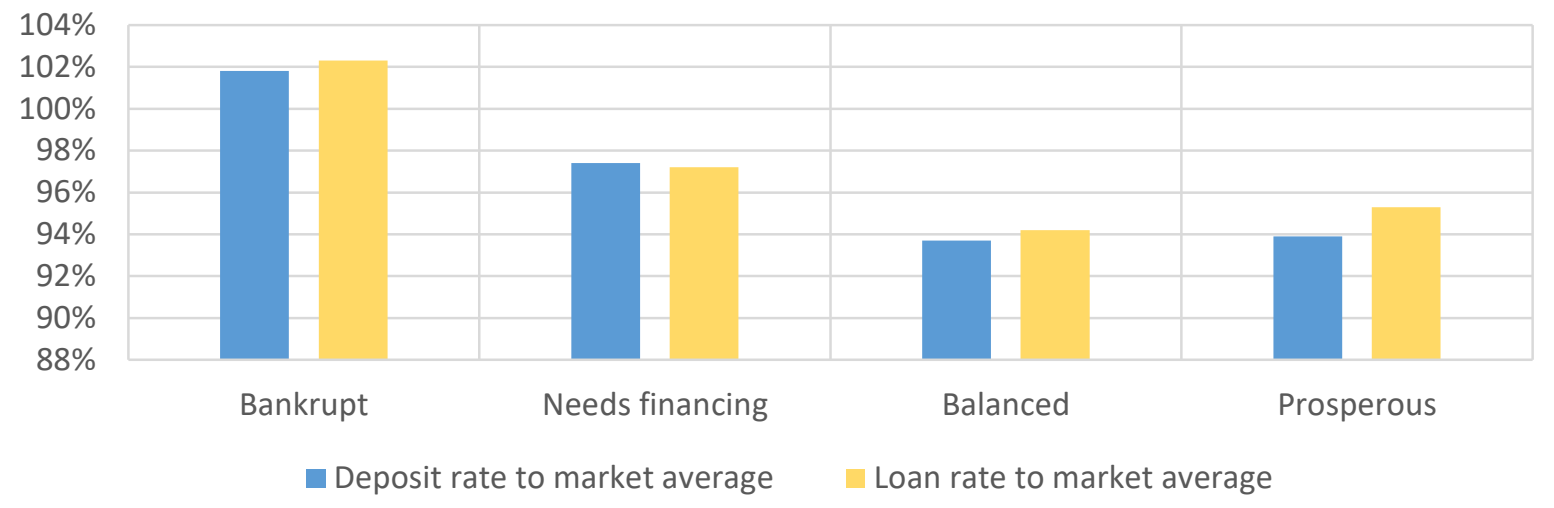

Figure 4. Interest rates over the respective market average

bank's future. On the other hand, greater public ownership seems to lead the bank to the balanced state more often, which is an expected result, since publicly owned banks tend to exhibit lower risk and lower profitability. The latter variable (public ownership) does not seem to exhibit a linear relationship with the dependent variable (final state).

Moving on to financial information, it is important to note the existence of "extreme" values for all states except the balanced state. It must also be noted that the amount of loans that bankrupt banks carry in their asset list is substantially higher than the other states. However, the existence of extreme values in the prosperous state leads us to deduce that banks cannot prosper if risks are not assumed. Nevertheless, it must be made clear to investors and depositors that these risks may result in bank failure. Risks must also be assumed by the financing department, where interestingly 
Table 2. Linear regression model for the prediction of the final state of the bank

\begin{tabular}{l|c|c}
\hline & B & Standard error \\
\hline (Constant) & -1.82 & 0.018 \\
CRO in board & 0.65 & 0.006 \\
Loans to deposits & -0.02 & 0.000 \\
Public ownership & -0.28 & 0.012 \\
Institutional ownership & 0.32 & 0.013 \\
CEO ownership & 0.19 & 0.013 \\
Deposit rate to average & -0.15 & 0.014 \\
\hline Loan rate to average & -0.36 & 0.029 \\
\hline
\end{tabular}

Note: The model's $\mathrm{R} 2$ value is 0.62 , which means that an important proportion of the variance in the dependent variable (Final State) can be predicted from the given set of independent variables. The specific value (0.62) shows that the model is a good fit for the given data set.

enough data for the NPLs ${ }^{8}$ and the interbank exposure at the snapshot period (period 10, as mentioned earlier) are similar for banks which ended up in the bankrupt and prosperous states, albeit interbank exposure is somewhat higher for the prosperous state.

With respect to the market position, it must be noted that the simulations appear to suggest an interest rate strategy for banks. The findings show that offering lower interest rates, vis-à-vis the market average, both for deposits and for loans, will improve the bank's future, the particulars of the prisoner's dilemma notwithstanding. A lower interest rate spread is also advisable, as is the use of a lower profit margin, even though the results are not clear on the latter.

A simple linear regression on the results shows that the important variables are the presence of the CRO in the board, the ownership variables and the interest rate strategy variables. These were included in the final prediction model.

It is not surprising that the public ownership variable does not exhibit high correlation, since, as was shown earlier, its relationship with the final state is not a linear one and consequently a linear regression of these variables will fail to describe the dependent variable's values. Admittedly, the use of a linear regression is simplistic and is one of the shortcomings of the current work. However, as one will see below, the linear regression is successful in describing the model and the resulting forecasting system can predict the bank's final state with a fair amount of certainty.
Table 2 shows the coefficients for the variables in the proposed prediction model, which are significant at the 95\% confidence level. This regression model has a satisfactory $\mathrm{R}^{-2}$ value and was implemented in the model in an effort to predict the final state of the financial institution. Once the prediction model was implemented, the simulations were executed 1,000 more times to verify robustness and the outcome (displayed in Table 3) was encouraging. On the snapshot period, the financial variables were calculated and used in conjunction with the governance variables in order to compute a prediction for the bank's final state. The authors let the simulation complete and compared the predicted state to the actual final state.

Table 3. Robustness check of the prediction model over 1,000 simulations

\begin{tabular}{l|c}
\hline & $\begin{array}{c}\text { Percentage, } \\
\%\end{array}$ \\
\hline Successful prediction & 64.25 \\
\hline Unsuccessful prediction & 35.75 \\
\hline Better state than predicted & 57.98 \\
\hdashline Worse state than predicted & 42.02 \\
\hline
\end{tabular}

In most cases, the prediction model was successful in forecasting the bank's final state, since in only $35 \%$ of the simulations the prediction was false. In these latter cases, only $42 \%$ would be damaging to the investors, since the final state of the bank was worse than the predicted one. Consequently, even though one can argue that a prediction of a worse state than the final one can also prove damaging, only a mere $15 \%$ of predictions could make an investor or depositor worse off if they followed it.

8 Non-Performing Loans. 


\section{CONCLUSION}

Concluding this paper, the authors have shown that both governance and financial variables need to be taken into account when discussing bank viability and when predicting whether the bank has enough potential to handle a financial crisis. The findings agree with the relevant literature, which places emphasis on the presence of a CRO in the board of directors, on board independence and on the ownership structure of the financial institutions, when discussing bank performance and hence viability.

Additionally, the introduction of a low interest rate strategy is proposed, which needs further verification though, since it appears to be a case of prisoner's dilemma. If all banks follow this strategy, then it will simply be ineffective. Consequently, a bank will need to be careful when using this strategy as a tool for better results.

The findings have also led to a simple, linear prediction model for the bank's end state, but it must be noted that the effectiveness is limited to the economic system of the agent-based model in its current version. The model seems to fail to predict a worse-off final state in only $15 \%$ of cases.

The empirical results have some important policy implications. Banking supervision pays little importance to the corporate governance features of the financial institutions. Additionally, authorities seem to focus more on capital requirements, which have been shown to hinder banking activity, with negative effects on the real economy and society. The results of the simulations suggest that regulators should take into account management characteristics of each bank as well. Policy makers can use this information to improve their stress testing systems in order to yield better results. The lack of statistical significance for commonly quoted figures, such as the NPLs and the interbank exposure, implies that banking authorities need to evolve their models and include more characteristics which might not have been taken previously into account. In today's corporate environment, where the role of banks is not limited to financial services but extends to many aspects of the modern society, bank failure can have severe adverse effects in community prosperity.

\section{REFERENCES}

1. Aebi, V., Sabato, G., \& Schmid, M. (2012). Risk management, corporate governance, and bank performance in the financial crisis. Journal of Banking \& Finance, 36(12), 3213-3226. https://doi.org/10.1016/j.jbankfin.2011.10.020

2. Agoraki, M. E. K., Delis, M. D., \& Staikouras, P. K. (2010). The effect of board size and composition on bank efficiency. International Journal of Banking, Accounting and Finance, 2(4), 357-386. https://doi. org/10.1504/IJBAAF.2010.037155

3. Barr, R. S., Seiford, L. M., \& Siems, T. F. (1993). An envelopmentanalysis approach to measuring the managerial efficiency of banks. Annals of Operations Research, 45(1), 1-19. https://doi. org/10.1007/BF02282039
4. Barry, T. A., Lepetit, L., \& Tarazi, A. (2011). Ownership structure and risk in publicly held and privately owned banks. Journal of Banking \& Finance, 35(5), 13271340. https://doi.org/10.1016/j. jbankfin.2010.10.004

5. Battese, G. E., \& Coelli, T. J. (1995). A model for technical inefficiency effects in a stochastic frontier production function for panel data. Empirical Eeconomics, 20(2), 325-332. https://doi.org/10.1007/ BF01205442

6. Beltratti, A., \& Stulz, R. M. (2009). Why Did Some Banks Perform Better during the Credit Crisis? A Cross-Country Study of the Impact of Governance and Regulation (Fisher College of Business Working Paper No. 2009-03-012). https://doi.org/10.3386/w15180
7. Bookstaber, R., Paddrik, M., \& Tivnan, B. (2018). An agentbased model for financial vulnerability. Journal of Economic Interaction and Coordination, 13(2), 433-466. Retrieved from https://link. springer.com/article/10.1007/ s11403-017-0188-1\#citeas

8. Broll, U., Guo, X., Welzel, P., \& Wong, W. K. (2015). The banking firm and risk taking in a two-moment decision model. Economic Modelling, 50, 275-280. https://doi.org/10.1016/j.econmod.2015.06.016

9. Calluzzo, P., \& Dong, G. N. (2015). Has the financial system become safer after the crisis? The changing nature of financial institution risk. Journal of Banking \& Finance, 53, 233-248. 
https://doi.org/10.1016/j.jbankfin.2014.10.009

10. Conyon, M. J., \& Peck, S. I. (1998). Board size and corporate performance: evidence from European countries. The European Journal of Finance, 4(3), 291-304.

11. Drehmann, M., \& Tarashev, N. (2013). Measuring the systemic importance of interconnected banks. Journal of Financial Intermediation, 22(4), 586607. https://doi.org/10.1016/j. jfi.2013.08.001

12. Drehmann, M., Sorensen, S., \& Stringa M. (2010). The integrated impact of credit and interest rate risk on banks: A dynamic framework and stress testing application. Journal of Banking \& Finance, 34(4), 713-729.

13. ElKelish, W. W. (2017). Corporate governance risk and the agency problem. Corporate Governance: The International Journal of Business in Society, 18(2), 254-269. https://doi.org/10.1108/CG-082017-0195

14. García-Marco, T., \& Robles-Fernández, M. D. (2008). Risk-taking Behaviour and Ownership in the Banking Industry: The Spanish evidence. Journal of Economics and Business, 60(4), 332-354. https://doi.org/10.1016/j.jeconbus.2007.04.008

15. García-Palacios, J. H., Hasman, A., \& Samartín, M. (2014). Banking crises and government intervention. Journal of Financial Stability, 15, 32-42. https://doi. org/10.1016/j.jfs.2014.08.007

16. Gupta, K., Krishnamurti, C., \& Tourani-Rad, A. (2013). Is corporate governance relevant during the financial crisis? Journal of International Financial Markets, Institutions and Money, 23, 85-110. https://doi.org/10.1016/j.intfin.2012.10.002

17. Haq, M., \& Heaney, R. (2012). Factors determining European bank risk. Journal of International Financial Markets, Institutions and Money, 22(4), 696-718.

18. Haque, F., \& Shahid, R. (2016). Ownership, risk-taking and performance of banks in emerging economies: Evidence from India. Journal of Financial Economic Policy, 8(3), 282-297. https://doi.org/10.1108/JFEP-092015-0054

19. Huang, X., Zhou, H., \& Zhu, H. (2009). A framework for assessing the systemic risk of major financial institutions. Journal of Banking \& Finance, 33(11), 2036 2049.

20. Iannotta, G., Nocera, G., \& Sironi, A. (2007). Ownership structure, risk and performance in the European banking industry. Journal of Banking \& Finance, 31(7), 2127-2149.

21. Kangis, P., \& Kareklis, P. (2001). Governance and organisational controls in public and private banks. Corporate Governance: The International Journal of Business in Society, 1(1), 31-38.

22. Karas, A., Pyle, W., \& Schoors, K. (2013). Deposit insurance, banking crises, and market discipline: Evidence from a natural experiment on deposit flows and rates. Journal of Money, Credit and Banking, 45(1), 179200. https://doi.org/10.1111/ j.1538-4616.2012.00566.x

23. Kaur Virk, G. (2017). The influence of board characteristics on corporate illegality. Journal of Financial Regulation and Compliance, 25(2), 133-148. https://doi.org/10.1108/JFRC-052016-0045

24. Koerniadi, H., Krishnamurti, C., \& Tourani-Rad, A. (2014). Corporate governance and the variability of stock returns. International Journal of Managerial Finance, 10(4), 494510. https://doi.org/10.1108/IJMF08-2012-0090

25. Konishi, M., \& Yasuda, Y. (2004) Factors affecting bank risk taking: Evidence from Japan. Journal of Banking \& Finance, 28(1), 215-232.

26. Laeven, L., \& Levine, R. (2009). Bank Governance, Regulation and Risk Taking. Journal of Financial Economics, 93(2), 259-275.

27. Macey, J. R., \& O’Hara, M. (2003). The corporate Governance of Banks. Economic Policy Review, 9(1).

28. Mullineux, A. (2006). The corporate governance of banks. Journal of Financial Regulation and Compliance, 14(4), 375-382.

29. O’Connor, T., \& Byrne, J. (2015) Governance and the corporate life-cycle. International Journal of Managerial Finance, 11(1), 23-43. https://doi.org/10.1108/IJMF-032013-0033

30. Philippas, D., Koutelidakis, Y., \& Leontitsis, A. (2015). Insights into European interbank network contagion. Managerial Finance, 41(8), 754-772. https://doi. org/10.1108/MF-03-2014-0095

31. Polyzos, S., \& Samitas, A. (2015). Banking Crises \& Contagion: Why Worry About Taxation, Output and the Cost of Capital? Investment Management and Financial Innovations, 12(2). Retrieved from https://businessperspectives.org/component/zoo/ banking-crises-and-contagionwhy-worry-about-taxation-output-and-the-cost-of-capital

32. Reddy, K., \& Locke, S. (2014). The relationship between ownership structure, capital structure and corporate governance practices: A case study of cooperatives and mutuals in New Zealand. International Journal of Managerial Finance, 10(4), 511536. https://doi.org/10.1108/IJMF12-2012-0130

33. Riccetti, L., Russo, A., \& Gallegati, M. (2016). Financialisation and crisis in an agent based macroeconomic model. Economic Modelling, 52, 162-172. https:// doi.org/10.1016/j.econmod.2014.11.028

34. Samitas, A., \& Polyzos, S. (2016). Freeing Greece from capital controls: Were the restrictions enforced in time? Research in International Business and Finance, 37, 196-213. https://doi. org/10.1016/j.ribaf.2015.11.005

35. Samitas, A., \& Polyzos, S. (2015). To Basel or not to Basel? Banking crises and contagion. Journal of Financial Regulation and Compliance, 23(3), 298-318. https://doi.org/10.1108/JFRC-112014-0045 
36. Samitas, A., Polyzos, S., \& Siriopoulos, C. (2018). Brexit and financial stability: An agentbased simulation. Economic Modelling, 69, 181-192. https:// doi.org/10.1016/j.econmod.2017.09.019

37. Simper, R., Hall, M. J., Liu, W., Zelenyuk, V., \& Zhou, Z. (2015) How relevant is the choice of risk management control variable to non-parametric bank profit efficiency analysis? The case of South Korean banks. Annals of Operations Research, 250(1), 105-127. https://doi.org/10.1007/ s10479-015-1946-x

38. Sullivan, R. J., \& Spong, K. R. (2007). Manager Wealth Concentration, Ownership
Structure and Risk in Commercial Banks. Journal of Financial Intermediation, 16(2), 229-248.

39. Tsomocos, D. P. (2003a). Equilibrium analysis, banking and financial instability. Journal of Mathematical Economics, 39(5), 619-655.

40. Tsomocos, D. P. (2003b). Equilibrium analysis, banking, contagion and financial fragility (Bank of England Working Paper No. 175).

41. Williams, J., \& Nguyen, N. (2005). Financial liberalisation, crisis, and restructuring: A comparative study of bank performance and bank governance in South East Asia. Journal of Banking \& Finance, 29(8), 2119-2154.
42. Wong, J., Wong, T. C., \& Leung, P. (2007). A Leading Indicator Model of Banking Distress - Developing an Early Warning System for Hong Hong and Other EMEAP Economies December 18, 2007 (Hong Kong Monetary Authority Working Paper No. 22/2007).

43. Wong, J., Wong, T. C., \& Leung, P. (2010). Predicting banking distress in the EMEAP economies. Journal of Financial Stability, 6(3), 169-179. https://doi.org/10.1016/j. jfs.2010.01.001

44. Wu, X., \& Li, H. (2015). Board independence and the quality of board monitoring: evidence from China. International Journal of Managerial Finance, 11(3), 308328. https://doi.org/10.1108/IJMF07-2014-0101 